\title{
TINDAK TUTUR GURU DAN MURID DI SMA NEGERI 1 KELUA KABUPATEN TABALONG
}

\author{
Hj. Ida Komalasari dan Akhmad Ramadhani \\ STKIP PGRI Banjarmasin \\ Email: idakomalasari56@gmail.com
}

\begin{abstract}
Abstrak
Sekolah merupakan salah tempat terjadinya peristiwa tutur antara guru dan murid. Peristiwa tutur tersebut akan menunjukan suatu tindak tutur. Oleh karena itu, peneliti melakukan penelitian tentang tindak tutur guru dan murid di SMA Negeri 1 Kelua dengan tujuan mendeskripsikan bentuk guru dan murid di SMA Negeri 1 Kelua. Metode yang digunakan dalam penelitian adalah metode deskriptif yang berusaha menggambarkan sesuatu yang terjadi dengan apa adanya, dan bertujuan untuk memperoleh informasi mengenai keadaan dan melihat kaitannya dengan variabel-variabel yang telah ditentukan. Sumber data yang digunakan dalam penelitian ini adalah percakapan yang berwujud wacana tutur yang berlangsung antara guru dan murid di SMA Negeri 1 Kelua dalam bentuk wujud pemakaian bahasa lisan. Teknik pengumpulan data yang digunakan adalah teknik observasi, teknik rekam, dan teknik transkrip.Teknik analisis data menggunakan metode deskriptif yaitu mengumpulkan, menyusun, menganalisis, dan mengiterpretasikan data. Hasil penelitian ini menunjukkan bahwa bentuk tindak tutur dalam proses pembelajaran maupun di luar proses pembelajaran sangan bervariasi tergantung dari tujuan yang akan dicapai, sehingga berbagai peristiwa tutur tidak hanya ditentukan oleh unsur-unsur kebahasaan secara struktural melainkan juga harus sesuai dengan prinsip-prinsip pemakaian bahasa serta bentuk tindak tutur yang digunakan juga harus tepat, karena mempengaruhi tingkat pemahaman peserta tutur terhadap makna yang dimaksud. Bentuk tindak tutur seperti lokusi, ilokusi, dan perlokusi.
\end{abstract}

\section{PENDAHULUAN}

Pada penjelasan tentang bahasa menjelaskan bahwa, dalam pemerolehan bahasa kenyataan anak sekolah rata-rata belum banyak menguasai kosakata dengan baik, hal ini dapat dilihat dari cara bicara yang digunakan oleh anak-anak. Peran guru sangat dibutuhkan dalam pengembangan kemampuan ujaran yang terjadi pada anak-anak. Berbicara tentu mempunyai tujuan menyampaikan maksud melalui bahasa. Maksud yang disampaikan seseorang dapat disampaikan secara tersirat ataupun tersurat. Untuk memahami maksud tersurat diperlukan pemahaman mengenai pragmatik. Pragmatik digunakan untuk berkomunikasi oleh penutur mengatur apa yang ingin mereka katakan yang sesuai dengan orang yang mereka ajak bicara dikarenakan pragmatik adalah salah satu studi tentang makna kontekstual. Keluasan kajian pragmatik bisa dipahami karena bahasa yang digunakan untuk berkomunikasi akan terkait dengan konteks, latar belakang penutur dan lawan tutur, serta tujuan berkomunikasi. Karena didunia bunyi dan dunia makna terdapat konteks. 
Tindak tutur merupakan gejala individual yang bersifat psikologis, dan keberlangsungannya ditentukan oleh kemampuan bahasa si penutur dalam meghadapi situasi tertentu. Dalam peristiwa tutur dilihat pada tujuan peristiwanya, tetapi dalam tindak tutur lebih memperhatikan pada makna atau arti tindakan dalam tuturannya. Dalam penelitian ini pendekatan pragmatik digunakan untuk mengkaji satuan analisis tindak ujaran atau tindak tutur. Dengan itu dapat diketahui apa fungsi tindak tutur itu diujarkan oleh penuturnya. Karena setiap ujaran yang dituturkan oleh penutur memiliki makna dan maksud tertentu sesuai dengan tujuan masing-masing. Tindak tutur dalam peristiwa tutur merupakan dua gejala yang terjadi pada suatu proses yaitu proses komunikasi. Di dalam kehidupan manusia tidak bisa lepas dari peristiwa tuturan, karena dengan tuturan manusia dapat menyampaikan informasi kepada lawan tuturnya serta dapat dimengerti satu sama lain. Tindak tutur merupakan bagian dari peristiwa tutur dan peristiwa tutur merupakan bagian dari situasi tutur. Setiap peristiwa tutur terbatas pada kegiatan atau aspek - aspek kegiatan yang secara langsung diatur oleh kaidah atau norma bagi penutur. Ujaran atau tindak tutur dapat terdiri atas satu tindak tutur sangat tergantung dengan konteks ketika penutur bertutur.Dan tuturan atau tindak tutur itu beraneka ragam jenisnya salah satunya pengelompokkan berdasarkan sifat hubungannya yang di dalamnya mencakup tindak tutur lokusi, ilokusi, dan perlokusi.

Dalam proses belajar mengajar di sekolah pun, guru dan murid melakukan peristiwa tutur atau berkomunikasi. Pada konteks tertentu guru harus bisa menggunakan bahasa yang baik dan sopan, begitu sebaliknya. Pada proses belajar mengajar dalam kelas guru dan murid berkomunikasi pada konteksnya, dan terjadinya peristiwa tutur yang menyebabkan proses tindak tutur lokusi, ilokusi dan perlokusi di dalam kelas maupun di luar kelas tersebut. Maka penelitian ini berusaha menjelaskan bagaimana bentuk tindak tutur lokusi, ilokusi, perlokusi guru dan murid di SMA Negeri 1 Kelua, yang bertujuan mendeskripsikan bentuk tindak tutur lokusi, ilokusi, perlokusi guru dan murid di SMA Negeri 1 Kelua.

Hal ini perlu dipertimbangkan bahwa Terjadinya peristiwa tutur dalam suatu komunikasi selalu diikuti oleh berbagai unsur yang tak terlepas dari konteksnya. Menurut Dell Hymes dalam Rohmadi (2004: 28), ada beberapa syarat terjadinya peristiwa tutur yang terkenal dengan akronim SPEAKING. Syarat-syarat terjadinya peristiwa tutur itu adalah; Setting dan Scene. Setting berkenaan dengan waktu dan tempat tuturan berlangsung, sedangkan scene mengacu pada situasi tempat dan waktu, atau situasi psikologis pembicara; Participant, adalah pihakpihak yang terlibat dalam pertuturan, bias pembicara dan pendengar, penyapa dan pesapa, atau pengirim dan penerima; Ends, merupakan maksud dan tujuan pertuturan; Act Sequance, mengacu pada bentuk da nisi ujaran yang digunakan oleh penutur; Key, mengacu pada cara dan semangat seorang penutur dalam menyampaikan pesan. Apakah dengan sombong, rendah hati, angkuh atau dengan cara yang lain; Instrumentalies, mengacu pada jalur bahasa yang digunakan 
seperti bahasa lisan, tertulis, isyarat dan lain-lain; Norm of interaction, mengacu pada norma atau aturan dalam berinteraksi; dan Genre, mengacu pada bentuk penyampaian suatu pesan. Apakah dalam bentuk puisi, prosa, do'a dan lain-lain. (Hymes, 1968: 99; dalam Suwito, 1983: 32).

Berdasarkan hal tersebut, maka tindak tutur adalah terjadinya atau berlangsungnya satu peristiwa interaksi linguistik yang menimbulkan arti atau makna dalam tuturannya. Menurut Austin tindak tutur di langsungkan dengan kalimat performatif di rumuskan sebagai peristiwa tindakan yang berlangsung sekaligus, yaitu (1) tindak tutur lokusi (2) tindak tutur ilokusi (3) tindak tutur perlokusi. Tindak tutur lokusi adalah tindak tutur yang menyatakan sesuatu dalam arti atau makna dapat di pahami. Tindak tutur ilokusi adalah tindak tutur yang berkenaan dengan nilai yang di bawakan oleh diposisinya. Tindak tutur perlokusi adalah tindak tutur yang berkenaan dengan adanya ucapan orang lain dan sikap dari nonlinguistik.

Konsep tindak tutur merupakan salah satu konsep yang cukup menonjol dalam perteorian linguistik masa kini. Konsep ini muncul beranjak dari upaya ilmiah dalam mengkaji fungsi bahasa dalam berkomunikasi secara konkret (berdasarkan pandangan fungsional), tidak hanya sekedar mengkaji bahasa untuk mendapatkan deskripsi tentang system bahasa (berdasarkan pandangan formal). Dalam kajian tindak tuntur, biasanya beranjak dari Austin dalam Putrayasa 2014: 86 (dalam Kasher, 1998), pakar filsafah dan linguistik dari Inggris tentang tindak tutur itu. Menurut Austin, kajian tentang makna haruslah tidak hanya mengonsentrasikan diri pada pernyataan-pernyataan kosong, lepas dari konteks, karena bahasa itu benar-benar dipakai dalam bentuk tutur, dalam berbagai fungsi atau dalam berbagai maksud dan tujuan. Ketika bertutur, kita memberi saran, berjanji, mengundang, meminta, melarang, dan sebagainya (Sumarsono, 2009 Putrayasa 2014: 86). Austin dalam Putrayasa 2014: 86, menegaskan juga bahwa terdapat banyak hal yang berbeda yang bias dilakukan dengan kata-kata. Sebagai ujaran bukanlah pernyataan atau pertanyaan tentang informasi tertentu, tetapi ujaran itu menyatakan tindakan (Ibrahim, 1992 dalam Putrayasa 2014:86). Sebagaimana yang dikatakan Milanowski, dalam beberapa hal kita memakai tututran untuk membentuk tindakan, bahkan dalam pengertian yang ekstrem, sering dikatakan, tuturan itu sendiri adalah tindakan (Sumarsono, 2009 dalam Putrayasa 2014:86). Secara lebih sederhananya, tindak tutur dapat diartikan tindakan yang direalisasikan dengan tuturan ataupun sebaliknya, tuturan yang direalisasi dengan tindakan.

\section{METODE}

Penelitian ini dilaksanakan di SMA Negeri 1 Kelua yang berlokasi di Jl. A. Yani KM. 4,5 Kelua Desa karangan Putih Kecamatan Kelua Kabupaten Tabalong. Ditetapkannya di SMA Negeri 1 Kelua Kabupaten Tabalong sebagai tempat penelitian dengan pertimbangan bahwa penelitian tentang tindak tutur 
sepengatahuan peneliti belum pernah dilaksanakannya penelitian tersebut. Dalam hal ini, penelitian bukan hanya difokuskan pada proses pembelajaran dalam kelas tetapi juga diluar proses pembelajaran luar kelas.

Untuk mencapai tujuan dan sesuai dengan masalah yang diteliti, penelitian ini menggunakan metode deskriptif. Sesuai dengan pendapat yang dikemukakan oleh Surahman (1982: 139) dalam Tiawati, 2012: 64 jurnal bahasa, metode deskriptif adalah metode yang dilakukan dengan jalan mengumpulkan, menyusun, menganalisis, dan menginterpresentasikan data. Hal ini sama dengan yang dikemukakan oleh Semi (1993: 23) dalam Tiawati, 2012: 64 jurnal bahasa, bahwa metode penelitian deskripsi adalah metode yang dilakukan dengan mendeskripsikan data yang diperoleh tanpa mengartikan dengan angka-angka, tetapi mengutamakan kedalaman penghayatan terhadap interaksi antara konsep yang sedang dikaji secara empiris. Penelitian dilaksanakan selama satu minggu dengan meneliti lima orang guru sebagai sampel dengan beda mata pelajaran pada saat pembelajaran dan beberapa guru saat di luar pembelajaran.

Dengan demikian, data yang diamati adalah bentuk percakapan atau wacana tutur yang muncul dalam interaksi antara guru dan murid di SMA Negeri 1 Kelua Kabupaten Tabalong. Dalam penelitian ini yang dijadikan sumber data adalah percakapan yang berwujud wacana tutur yang berlangsung antara guru dan murid di SMA Negeri 1 Kelua dalam bentuk pemakaian bahasa lisan yaitu tindak tutur.

Instrumen yang dipakai dalam penelitian ini adalah (a) kamera dan perekam handphone, serta (b) kartu data. Instrumenpenelitianini, penelitisebagai instrument

utama.Dalampenelitianinijugamenggunakanalatbantuberupaalatperekam audio darihandphone. Kamera dan perekam handphone digunakan sebagai alat perekam momen pada saat penelitian dan merekam percakapan guru dan murid di SMA Negeri 1 Kelua baik dalam proses pembelajaran maupun luar. Kartu data digunakan sebagai alat menganalisis transkip wacana tutur guru dan murid di SMA Negeri 1 Kelua.

Pengumpulan data yang digunakan dalam penelitian ini ada tiga teknik, yaitu observasi, rekam, dan transkrip. Teknik analisis data menggunakan metode deskriptif yaitu mengumpulkan, menyusun, menganalisis, dan menginterpretasikan data. Maka teknik yang digunakanuntukmenganilis data adalah sebagai berikut; mentranskripsikan tindak tutur guru dalam proses pembelajaran maupun di luar proses pembelajaran yang telah direkam berupa data lisan ke dalam bahasa tulis.; mengklasifikasikan tindak tutur lokusi, ilokusi, dan perlokusi guru dalam proses pembelajaran maupun di luar proses pembelajaran dengan menggunakan kartu data pada tabel 1 kartu data tindak tutur; menganalisis tindak tutur digunakan oleh guru dalam proses pembelajaran maupun di luar proses pembelajaran; dan melakukan penyimpulan data berdasarkan hasil penelitian. 


\section{HASIL DAN PEMBAHASAN}

Berdasarkan hasil observasi yang dilakukan peneliti untuk menganalisis bentuk tindak tutur guru dan murid di SMA negeri 1 Kelua, maka hasil penelitian dapat dideskripsikan dalam bentuk tabel data bahasa. Data bahasa digunakan untuk menggambarkan bentuk tindak tutur data secara umum. Dalam data bahasa peneliti memperoleh deskripsi terjadi 27 peristiwa tutur yang telah diteliti, setiap peristiwa tutur terdapat bentuk tindak tutur lokusi, ilokusi, perlokusi guru dan murid di SMA Negeri 1 Kelua.

Penggunaan bentuk tindak tutur guru dan murid di SMA Negeri 1 Kelua dalam proses pembelajaran maupun di luar proses pembelajaran akan terlaksana dengan baik dan lancar jika penggunaan tuturan tersebut sesuai dengan kondisi dan situasi yang terjadi secara berlangsung. Bentuk tindak tutur yang digunakan dapat berupa tindak tutur lokusi, tindak tutur ilokusi, dan tindak tutur perlokusi.

\section{A. Penggunaan Tindak Tutur Lokusi}

Tindak tutur lokusi merupakan jenis tindak tutur yang mengaitkan suatu topik dengan sesuatu keterangan dalam suatu ungkapan, atau bisa dikatakan bahwa bentuk lokusi merupakan suatu kalimat atau ujaran yang berupa pernyataan atau yang bersifat memberikan suatu informasi. Dengan menggunakan tindak tutur lokusi peserta tutur akan dapat dengan mudah memahami suatu konteks yang berhubungan dengan maksud yang diingnkan peserta tutur. Dengan kata lain, tindak tutur lokusi akan membantu guru dan murid dalam memahami suatu informasi melalui ujaran atau tuturan selama peristiwa berlangsung baik dalam proses pembelajaran maupun di luar proses pembelajaran. Penggunaan bentuk tindak tutur lokusi dapat diamati melalui peristiwa tutur di luar proses pembelajaran terjadi di depan kantor guru seperti di bawah ini.

$$
\begin{array}{lc}
\text { Kutipan 1 } & \\
\text { Hari/Tanggal } & \text { : Kamis, 28 April } 2016 \\
\text { Pukul } & : 09.30 \\
\text { Guru } & \text { : Nuryani, S. Pd } \\
\text { Tempat } & \text { : Depan kantor guru } \\
\text { Jam Pelajaran } & \text { : Di luar jam pelajaran }
\end{array}
$$

Murid :malam tadi ma sms, sapida mutur ku masih rusak bisa kada kawa turun bisa di alpa orang leh? ( Tadi malam me sms, sepeda motor aku masih rusak mungkin tidak bisa turun bisa tanpa keterangan/alpa guru ya?)

Guru :nyata ae mun di alpa, belajar kada. ( jelas lah tanpa keterangan, tidak belajar). (Peristiwa tutur 1)

Pada peristiwa tutur (1) menunjukan suatu informasi bahwa ketika seorang murid memberitahukan alasan tentang temannya tidak sekolah kepada guru, maka sang guru pun menanggapinya dengan juga memberikan informasin bukan hanya untuk murid yang tidak hadir tetapi juga murid yang memberikan informasi tersebut bahwa setiap murid yang tidak hadir ke sekolah tanpa keterangan maka murid itu tidak hadir dengan tanpa keterangan. Guru juga memberikan informasi bahwa murid yang tidak hadir itu tidak bisa ikut belajar seperti biasa.Berdasarkan 
peristiwa tutur (1) memperlihatkan kalau guru dan siswa sama-sama menginformasikan sesuai dengan dikehendaki oleh guru.Sehingga tuturan tersebut telah sesuai dengan bentuk tindak tutur lokusi yang menginformasikan sesuatu hal kepada peserta tutur saat tuturan itu terjadi.

Bentuk tindak tutur lokusi dapat dianalisis juga dalam proses pembelajaran yang dilakukan guru dalam kelas pada pelajaran Budi Pekerti kelas XI IPA 2 saat belajar mengajar berlangsung.

Kutipan 2

Hari/Tanggal : : Sabtu, 30 April 2016

Guru : Masyana, S. Pd

Tempat : Kelas XI IPA 2

Pelajaran : Budi Pekerti

Jam Pelajaran ke- : 2

Guru : contoh para Nabi begitu sabarnya beliau, mengahadapi cobaan allah, nabi Yakub dengan kemiskinan, nabi yusuf, nabi sulaiman.. kalau nabi sulaiman di uji dengan? ( contoh para Nabi begitu sabarnya mereka, mengahadapi cobaan Allah, nabi Yakub dengan kemiskinannya, nabi Yusuf, nabi Sulaiman. Kalau nabi Sulaiman diuji dengan?

Murid : dengan kekayaan bu ae (dengan kekayaannya bu). (Peristiwa tutur 3)

Peristiwa tutur (3) di atas guru menginformasikan kepada murid bahwa menjadi orang sabar itu contohlah para Nabi, karena menjadi orang sabar itu adalah hal yang baik dan akan mendapat balasannya. Maka guru menginformasikan tersebut agar murid-muridnya menjadi orang yang sabar dengan melihat contoh para Nabi.Jadi, peristiwa tutur (3) tersebut merupakan bentuk tindak tutur lokusi yaitu guru menginformasikan kepada muridnya tentang contoh menjadi orang sabar. Jika dianalisi lagi secara lebih mendalam lagi dalam proses pembelajaran maka indikasi bentuk tindak tutur lokusi digunakan oleh guru dalam proses pembelajaran berlangsung.

Bentuk tindak lokusi dalam proses pembelajaran mata pelajaran Budi Pekerti kelas XI IPA 2 digunakan oleh guru sebagai berikut.

Kutipan 3

Hari/Tanggal

Guru

Tempat

Pelajaran

Jam Pelajaran ke- : 2

Guru : meminta sesuatu itu pada orang ada ilmunya, contoh orang alim karena kealimannya, kedokter karena ada ilmunya, minta sesuatu karena kealimannya bisa minta doanya, ini ke dukun salah sholat aja kada dukun tu. ( meminta sesuatu itu pada orang yang ada ilmunya, contoh orang alim karena kealimannya, kedokter karena ada ilmunya, minta sesuatu karena kealimannya bisa didoakannya, ini mintanya ke dukun jelas salah dukun itu sholat aja tidak).

Murid : syirik (syirik)

Guru : iya syirik dosa besar kada di ampuni Allah, kalau dosadosa kecil masih bisa di ampuni Allah, tapi dosa besar kadada ampunannya , jadi seorang muslim jangan ke dukun. ( iya syirik dosa besar tidak diampuni oleh Allah, kalau dosa-dosa kecil masih 
bisa diampuni Allah, tapi kalau dosa besar tidak ada ampunannya, jadi seorang muslim jangan pergi ke dukun). (Peritiwa tutur 6)

Pada peristiwa (6) di atas juga termasuk dalam bentuk tindak tutur lokusi, karena guru memberikan informasi kepada murid tentang hal meinta sesuatu pada orang yang memang ada ilmunya apalagi sampai minta sesuatu pada dukun itu adalah sesuatu yang salah.Maka informasi yang diberikan guru pun ditanggapi murid bahwa hal tersebut adalah syirik.Peristiwa tutur di atas guru dan murid sama-sama memberikan informasi.Kemudian guru pun menerima informasi dari muridnya, dan menjelaskan lagi tentang informasi tersebut bahwa syirik itu adalah dosa besar. Jadi bentuk tindak tutur pada tuturan tersebut guru dan murid saling menginformasikan satu sama lain.

Bentuk tindak tutur lokusi terjadi lagi pada proses pembelajaran tersebut, guru dan murid sama-sama memberikan informasi pada tuturan berikut.

\section{Kutipan 4}

Hari/Tanggal

Guru

Tempat

Pelajaran

Jam Pelajaran ke-

Guru : kalau mau kaya bawa sholat duha disempatkan pagi sholat, fungsinya banyak pakai surat yang panjang. (kalau mau kaya bawa sholat duha disempatkan pada pagi hari, fungsinya banyak gunakan surat yang panjang).

Murid : wirid panjang (wirid panjang)

Guru : bukan wiridnya tapi surat dan doanya, karena sholat itu bisa membuat kita kaya, kaya rezeki, kaya hati, kaya kesehatan. Jadi buhan kam sebagai pelajar jangan minta kaya harta duit aja masih minta lawan kuitan. (bukan wirid tapi surat dan doanya, karena sholat duha itu bisa membuat kita kaya, kaya rezeki, kaya hati, kaya kesehatan. Jadi kalian sebagai pelajar jangan minta kaya harta, uang saja masih minta sama orang tua). (Peritiwa tutur 8)

Peristiwa tutur (8) menerangkan bahwa guru memberikan informasi tentang manfaat sholat duha di pagi hari, jika ingin kaya maka sholat duha menggunakan surat panjang. Pada tuturan tersebut tanggapan murid terhadap informasin tersebut berbeda, murid menanggapinya dengan wirid panjang. Sehingga guru pun menyanggah informasi murid, tuturan tersebut informasi dari guru bukan wirid panjang tapi menggunakan surat-surat Al-Quran yang panjang disertai doa. Kemudian guru pun memberikan informasi lagi bahwa sholat duha itu banyak manfaat untuk meminta sesuatu kepada Tuhan.Jelas terlihat bentuk tutur ilokusi pada tuturan tersebut saling memberikan informasi.

Proses pembelajaran mata pelajaran lain pun bentuk tindak tutur lokusi terlihat pada pelajaran Fisika kelas XI IPA 1, saat berlangsungnya pembelajaran sebagai berikut.

$\begin{array}{ll}\text { Kutipan 5 } & \\ \text { Hari/Tanggal } & \text { : Selasa, 03 Mei } 2016 \\ \text { Guru } & \text { : Saudah, ST } \\ \text { Tempat } & \text { : Kelas XI IPA 1 } \\ \text { Pelajaran } & : \text { Fisika } \\ \text { Jam Pelajaran ke- } & : 1-2\end{array}$


Guru :Kenapa salah-salah membaca Al-quran?. (kenapa baca Al-Qurannya banyak salah?)

Murid : gugup bu ae (gugup bu)

Guru : membaca quran itu sunat, membaca baik dan benar itu wajib, ingati kena-kena belajar lagi membaca quran. ( membaca Quran itu sunat, membaca baik dan benar itu wajib, ingat nanti-nanti belajar lagi membaca Quran). (Peristiwa Tutur 9)

Peristiwa tutur (9) di atas guru menanyakan kepada murid kenapa banyak salah ketika membaca Al-Quran, pertanyaan tersebut dijawab murid bahwa ketika membaca murid tersebut gugup.Tuturan tersebut setelah guru menerima informasi bahawa murid gugup saat membca Al-Quran, maka guru pun memberikan informasi tentang membaca Al-Quran dan hukumnya. Guru menegaskan informasinya bahwa membaca Al-quran itu sunat, sedangkan membaca baik dan benar itu adalah suatu kewajiban. Tuturan tersebut merupakan bentuk tindak tutur lokusi yaitu guru memberikan informasin kepada murid tentang membaca AlQuran.

B. Penggunaan Tindak Tutur Ilokusi

Tindak tutur ilukosi merupakan tindak tutur yang menginformasikan sesuatu yang dipergunakan untuk melakukan sesuatu.Dalam penggunaan bentuk tindak tutur ilokusi terkadang guru banyak melakukan bentuk tuturan untuk menerangkan atau membuat muridnya melakukan sesuatu sesuai dengan kehendak guru.Bentuk tindak tutur ilokusi memberikan informasi sesuatu tetapi juga untuk melakukan tindakan. Tuturan berikut mengindikasi adanya tuturan ilokusi pada peristiwa tutur yang terjadi depan kantor.

$\begin{array}{ll}\text { Kutipan 6 } & \\ \text { Hari/Tanggal } & \text { : Kamis, 28 April } 2016 \\ \text { Pukul } & \text { : } 09.30 \\ \text { Guru } & \text { : Nuryani, S. Pd } \\ \text { Tempat } & \text { : Depan kantor guru } \\ \text { Jam Pelajaran } & \text { : Di luar jam pelajaran } \\ \text { Guru : kadada alasan } & \text { dintu masalah apa }\end{array}$

Guru : kadada alasan dintu, masalah apa, masalah sapida muturkah rusak yang ngaran kewajiban tu barang kah umpat urang kah , harus berusaha. ( tidak ada alasan gitu, masalah apa, masalah sepeda motor kalau rusak yang namanya kewajiban itu terserah aja bisa ikut teman, harus berusaha). (Peristiwa tutur 1)

Tuturan guru di atas menginformasikan bahwa dalam melaksanakan suatu kewajiban harus ada usaha.Berdasarkan tuturan guru tersebut bukan hanya informasi melaksanakan kewajiban harus ada usaha, tetapi juga guru tersebut juga bermaksud kepada muridnya untuk melakukan usaha tersebut.Seperti yang dituturkan oleh guru usaha itu bisa ikut teman kalau sepeda motornya rusak, seperti itu yang dimaksud oleh tuturan guru.Jadi, peristiwa tutur (1) guru tersebut tidak hanya memberikan informasi tetapi juga dipergunakan untuk melakukan suatu tindakan.Sehingga pada tuturan tersebut termasuk bentuk tindak tutur ilokusi.

Bentuk tindak tutur ilokusi sering ditemukan juga pada saat proses pembelajaran seperti pada pelajaran Budi Pekerti kelas XI IPA 2 di bawah ini.

Kutipan 7

Hari/Tanggal

Guru

: Sabtu, 30 April 2016

: Masyana, S. Pd 


Tempat $\quad$ Kelas XI IPA 2
Pelajaran
Jam Pelajaran ke- $\quad:$ Budi Pekerti
Guru :Misalnya ada yang menyambati buhan kam , inya
manyambati ikam bungas pintar, belum tentu inya nyambati yang
kada baik lalu ja handak sarik ditambah ada yang salah bawa pandir.
(Misalnya ada yang mengejek kalian, dia bilang kamu cantik, pintar,
jadi belum tentu dia bilang yang tidak baik lalu ingin marah tambah
ada yang salah membawa pembicaraan tersebut).
Murid : berburuk sangka badahulu. (Berburuk sangka duluan).
(Peristiwa tutur 4)

Tuturan di atas guru menyampaiakan informasi dan tindakan pun dimengerti oleh muridnya. Pada peristiwa (4) guru menginformasikan kepada murid bahwa kalau ada teman yang lain mengejek si murid belum tentu dia mengejek yang tidak baik, tetapi teman yang lain bilangnya yang baik. Sehingga pada tuturan guru memberikan informasi tapi juga guru mengharapkan tindakan dari informasi tersebut.Tuturan guru itu ditanggap oleh murid bahwa itu perilaku berburuk sangka pada teman, maka tuturan guru menyampaikan informasi dan harapannya agar murid melakukan tindakan pun tercapai yaitu murid paham dengan maksud guru itu agar tidak melakukan hal itu.Tuturan itu merupakan bentuk tindak tutur ilokusi yang dilakukan guru kepada murid.Bentuk tindak tutur ilokusi ditemukan juga pada tuturan berikut ini.

$\begin{array}{ll}\text { Kutipan } 8 & \\ \text { Hari/Tanggal } & \text { : Sabtu, 30 April } 2016 \\ \text { Guru } & \text { : Masyana, S. Pd } \\ \text { Tempat } & \text { : Kelas XI IPA 2 } \\ \text { Pelajaran } & : \text { Budi Pekerti } \\ \text { Jam Pelajaran ke- } & : 2\end{array}$

Guru : Bila ada masalah berkeluh kesahlah pada Allah, hape mu tu canggih, bila malam jangan bakisah lawan kawan siapa tahu kawan yang madahi ka lain. (Bila ada masalah berkeluh kesahlah pada Allah, Hp kalian kan canggih, bila malam jangan bercerita sama teman siapa tahu teman kalian bilang ke teman yang lain).

Murid : muka dua. (bermuka dua). (Peristiwa tutur 7)

Peristiwa tutur (7) tuturan guru memberikan informasi kepada murid agar muridnya melakukan tindakan tercapai. Guru memberikan informasi kepada murid agar berkeluh kesah sesuatu itu hanya pada Tuhan, yang mana guru juga mengharapkan tindakan kepada murid agar tidak berkeluh kesah pada teman karena saat ini handphone luar biasa canggihnya. Guru menginformasikan kalau berkeluh kesah dengan teman, guru khawatir isi keluh kesah itu dibicarakan keteman lainnya. Melalui informasi dari tuturan guru tersebut murid pun memberi tanggapan berupa tindakan yaitu orang seperti itu adalah orang yang bermuka dua.Berarti dari tuturan itu guru berharap tindakan murid agar tidak bermuka dua.Sehingga pada tuturan tersebut pun termasuk bentuk tindak tutur ilokusi.

Pada proses pembelajaran Fisika kelas XI IPA 1 juga ditemukan bentuk tindak tutur ilokusi yang dilakukan guru dan murid sebagai berikut ini.

Kutipan 9

Hari/Tanggal

Guru

: Selasa, 03 Mei 2016

: Saudah, ST 


$\begin{array}{ll}\text { Tempat } & \text { : Kelas XI IPA 1 } \\ \text { Pelajaran } & \text { : Fisika } \\ \text { Jam Pelajaran ke- } & : 1-2\end{array}$

Guru : galambungan tu jangan ditiup langsung aja diikat andak di panas makanya galambungan tu akan baganal. (balon itu jang ditiup langsung aja diikat letakkan dipanas maka balon itu akan membesar)

Murid : masa bu (masa bu). (Peristiwa tutur 13)

Tuturan tersebut guru memberikan informasi kepada murid bahwa balon itu bisa membesar tanpa ditiup dan diikat kalau ditaruh di bawah panas.Peritiwa tutur (13) guru bukan hanya memberikan informasi tentang hal balon tersebut tetapi guru juga berharap adanya tindakan murid agar melakukan sesuai dengan informasi guru. Tapi, tanggapan murid terhdap informasi yang diberikan guru, ditanggap dengan jawaban tidak yakin "masa bu", padahal guru guru mengharapkan tindakan untuk melakukan sesuai informasi itu sebagai pembuktian benar atau salahnya informasi tersebut. Tuturan guru tersebut juga termasuk bentuk tindak tutur ilokusi yaitu memberikan informasi dengan mengharap tanggapan dalam tuturannya.Bentuk tindak tutur ilokusi juga diindikasi pada tuturan berikut ini.

$\begin{array}{ll}\text { Kutipan } 10 & \\ \text { Hari/Tanggal } & \text { : Selasa, 03 Mei } 2016 \\ \text { Guru } & : \text { Saudah, ST } \\ \text { Tempat } & : \text { Kelas XI IPA 1 } \\ \text { Pelajaran } & : \text { Fisika } \\ \text { Jam Pelajaran ke- } & : 1-2\end{array}$

Guru : mahram itu siapa ?mahram yang boleh melihat tu ayah ibu kaka laki-laki kamanakan laki-laki semuanya dijelaskan di ayat 30 An Nur. Perempuan muslim itu boleh makai parhiasan yaitu pada tempatnya, tempat perhiasan kalung di leher, gelang dipergelangan, dibatis galang batis tapi kada boleh memperlihatkan. Jadi sesama muslimah ada batasannya.Jadi kada boleh jua badangsanakan mandi badua. (mahram itu siapa? Mahram yang boleh melihat itu ayah, ibu, kaka, keponakan laki-laki semuanya dijelaskan di ayat 30 An Nur. Perempuan muslim itu boleh menggunakan perhiasan pada tempatnya, tempat perhiasan kalung di leher, gelang di pergelangan, dikaki gelang kalitapi kada boleh memperlihatkannya. Jadi sesama muslimah ada batasannya.Jadi tidak boleh juga bersaudara mandi berdua). (Peristiwa tutur 16)

Tuturan di atas guru menginformasikan kepada murid tentang mahram yang boleh melihat aurat dalam keluarga sesuai dengan ayat 30 An Nur, selain menginformasikan guru juga mengaharapkan tindak murid untuk melakukan hal seperti itu yang sesuai ayat 30 An Nur.Dalam tuturan tersebut, guru juga menginformasikan kalau perempuan muslimah itu memang boleh memakai perhiasan sesuai dengan tempatnya seperti kalung, gelang, anting, dan anting.Guru juga mengaharapkan tindakan kalau diperbolehkan menggunakan perhiasana tapi jangan diperlihatkan.Karena dalam tuturan tersebut guru menginformasikan bahwa seorang muslimah itu ada batasannya, walaupun bersaudara jangan sampai juga mandi berdua.Peristiwa tutur (16) guru memberikan informasi kepada murid agar murid melakukan tindakan yang sesuai 
informasi guru tersebut.Selain memberikan informasi guru juga berharap agar murid tersebut melakukan tindakan sesuai informasi guru.

\section{Penggunaan Tindak Tutur Perlokusi}

Tindak tutur perlokusi selain memberikan informasi tetapi juga mempengaruhi lawan tuturnya.Hal yang dimaksud tersebut adalah konteks yang terjadi atau yang mengiringi saat terjadinya tuturan. Dalam proses pembelajaran maupun di luar proses pembelajaran pasti terdapat bentuk tindak tutur perlokusi ini, karena makna yang akan dipahami oleh peserta tutur selain memberikan informasi tetapi juga mempengaruhi lawan tutur dari makna ujaran dan makna dari tuturan antara guru dan murid. Bentuk tindak tutur perlokusi dalam proses pembelajaran di kelas saat pelajaran Budi pekerti di kelas XI IPA 2 sebagai berikut.

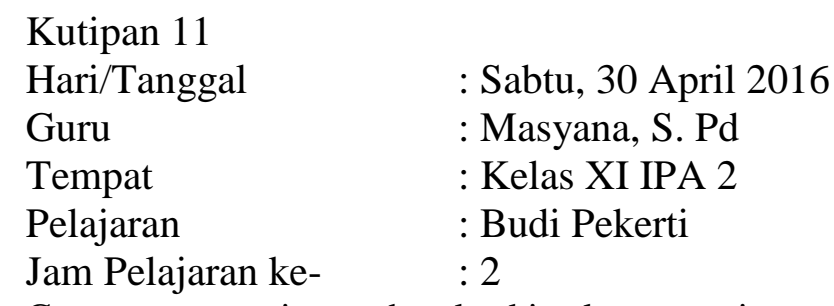

Guru : sariawan betul, kita langsung intropeksi diri kenapa aku sakit mulut oh kemungkinan aku sering menyambati kawan, untuk intropeksi diri kenapa Allah mendatang penyakitku pada mulut. ( sariawan benar. Kita langsung intropeksi diri kenapa aku sakit mulut kemungkinan aku sering mengejek teman, untuk intropeksi diri kenapa Allah memberk penyakit pada mulutku).

Murid : supaya jangan menyambati orang. ( agar jangan mengejek/menggosip orang). (Peristiwa tutur 3 )

Tuturan guru di atas merupakan tindak tutur perlokusi, karena guru memberikan informasi.Tetapi peristiwa tutur (3) guru juga mempengaruhi murid agar mengerti bahwa segala macam penyakit itu datang harus selalu intropeksi diri, maknanya jangan menyalahkan keadaan tapi intropeksi diri. Dari informasi tersebut murid pun merespon kalau itu benar, karena akibatnya penyakit itu mungkin sering mengejek orang lain. Maka makna yang disampaikan guru lebih mudah diterima oleh murid.Peristiwa tutur (3) merupakan bentuk tindak tutur perlokusi.

$\begin{array}{ll}\text { Kutipan } 12 & \\ \text { Hari/Tanggal } & : \text { Sabtu, 30 April } 2016 \\ \text { Guru } & \text { : Masyana, S. Pd } \\ \text { Tempat } & : \text { Kelas XI IPA 2 } \\ \text { Pelajaran } & : \text { Budi Pekerti } \\ \text { Jam Pelajaran ke- } & : 2\end{array}$

Guru : hilang duit minta banyu, hilang polpen minta banyu itu salah, coba kedokter karena ada ilmunya, orang alim mendoakan. Contohnya ke dukun bapadah panas owh ada api jer dukun mun bapadah dingin salju jer, coba badiam aja datang tu inya kada bisa manabak, orang percaya dukun sarba tahu itu salah. Makanya sebagi muslim dan berpendidikan jangan sampai ke dukun di ungulinya. (hilang uang minta air, hilang polpen minta air itu salah. Coba dokter karena ada ilmunya, orang alim mendoakan. Contohnya ke dukun bilang panas badan maka ada api kata dukun mungkin kalau kita bilang dingin bisa salju katanya. Coba datang itu diam aja mungkin 
dia tidak bisa menebak, orang percaya dukun karena serba tahu itu salah. Makanya sebagai muslim dan berpendidikan jangan samapai ke dukun itu dibodohinya). (Peritiwa tutur 6)

Peristiwa tutur (6) bukan hanya memberikan informasi bahwa meminta sesuatu ke dukun itu adalah hal yang salah. Tetapi juga mempengaruhi murid agar tidak melakukan hal itu karena sebagai seorang yang muslim dan berpendidikan jangan sampai ke dukun. Efek dari itu berpengaruh bagi murid agar murid sebagai orang yang berpendidikan agar tidak meminta bantuan ke dukun.Jadi, peristiwa tutur (6) merupakan bentuk tindak tutur perlokusi.

Proses pembelajaran lain pun ditemukan tindak tutur perlokusi pada pelajaran Fisika di kelas XI IPA 1 terjadi peristiwa tutur seperti di bawah ini.

Kutipan 13

Hari/Tanggal

Guru

: Selasa, 03 Mei 2016

Tempat

: Saudah, ST

Pelajaran

: Kelas XI IPA 1

Jam Pelajaran ke-

: Fisika

Guru : kasurnya harus di halat, lawan guling kah atau bantal. Kenapa, Nabi yang madahi kayatu, Nabi kan dapat wahyu dari Allah. Jadi, Allah tahu lemahnya manusia. Kalau sampai satu selimut siapa yang tahu akan terjadi yang sesama jenis walau pun kawan akrab mun satu selimut siapa yang tahu , makanya Allah tahu lemahnya Manusia. Bisa jadi gay, lesbian itu yang akan terjadi karana pargaulan. ( kasurnya harus dibatasi, sama guling atau bantal. Kenapa, Nabi bilang seperti itu, Nabi dapat wahyu dari Allah.Jadi, Allah tahu lemahnya manusia. Kalau sampai satu selimut siapa tahu akan terjadi yang sesama jenis walaupun teman dekat kalau satu selimut siapa yang tahu! Makanya Allah tahu lemahnya manusia. Bisa jadi gay, lesbianitu yang akan terjadi karena pergaulan). (Peristiwa tutur 15)

Peristiwa tutur (15) selain memberikan informasi bahwa kasur itu harus dibatasi, guru juga mengingatkan kepada murid karena Tuhan tahu lemahnya manusia.Makna dari tuturan tersebut agar murid tidak melakukan hal seperti itu walaupun dengan teman akrab.Pada konteksnya guru memberikan informasi ini karena pergaulan sekarang semakin memprihatinkan, guru mempengaruhi murid agar tidak seperti itu.Tuturan tersebut memberikan informasi sekaligus maknanya agar murid bisa memahami tentang pergaulan pada zaman sekarang ini jadi harus berhati-hati dan jangan sampai melakukannya.Saat pembelajaran pelajaran Matematika di kelas XI IPA 2 juga diindikasi adanya bentuk tindak tutur perlokusi sebagai berikut.

$\begin{array}{ll}\text { Kutipan 14 } & \\ \text { Hari/Tanggal } & \text { : Rabu, 04 Mei 2016 } \\ \text { Guru } & \text { : Amalia Rahmi, S. Pd, M. Pd } \\ \text { Tempat } & \text { : Kelas XI IPA 2 } \\ \text { Pelajaran } & : \text { Matematika } \\ \text { Jam Pelajaran ke- } & : 5-6\end{array}$

Guru : boleh, tapi jangan soal PR itu yang di padahi, ibu bahari kayatu jua, PR ibu tirukan ngumpul dapat 100 berataan tapi ulangan kakawanan dapat 0 ibu dapat 100 sorangan. Sama Atta kayatu konsepnya. (boleh, tapi jangan soal PR itu yang dicontekkan, ibu 
dulu seperti itu juga, PR ibu contekkan dikumpul dapat 100 semuanya tapi ketika ulangan teman-teman dapat 0 ibu dapat 100 sendirian, sama Atta seperti itu juga konsepnya)

Murid : mana ada bu! (tidak ada bu!)

Guru : tahu walaupun dalam hati kada kaitu maksudnya tapi akibatnya membuat kakawanan bodoh. Tapi kakawanan ni handak soal itu yang dipadahi iya kalu.(tahu walaupun dalam hati tidak seperti itu maksudnya tapi akibatnya membuat teman-teman bodoh. Tapi teman-teman ini maunya soal itu yang dikasih tahu). (Peristiwa tutur 18)

Tuturan di atas pun merupakan bentuk tindak tutur perlokusi, guru menginformasikan bahwa kalau menyontekkan teman itu tidak boleh. Guru juga memberikan contoh berdasarkan pengalaman dia agar muridnya tidak seperti itu, itu merupakan konteks agar murid tidak melakukan hal seperti itu.Berdasarkan informasi itu murid pun merespon dan menanggapi bahwa dirinya tidak seperti gurunya ceritakan. Guru itu juga menegaskan bahwa murid yang lain jangan lagi menyontek sama temannya. Konteks tuturan tersebut guru memberikan informasi agar murid memahami makna dari yang disampaikan guru kepada murid.Bagitu halnya dalam peristiwa tutur (18) adalah bentuk tindak tutur perlokusi.

Pelajaran Biologi di kelas X-3 pada saat berlangsungnya proses pembelajaran ditemukan peristiwa tutur yang diindikasi adanya bentuk tindak tutur perlokusi seperti dibawah ini.

$\begin{array}{ll}\text { Kutipan 15 } & \\ \text { Hari/Tanggal } & \text { : Rabu, 04 Mei } 2016 \\ \text { Guru } & \text { : Tina Erlida, S. Pd } \\ \text { Tempat } & \text { : Kelas X-3 } \\ \text { Pelajaran } & : \text { Biologi } \\ \text { Jam Pelajaran ke- } & : 5-6\end{array}$

Guru : ingati bagi yang tadi catatan balum lengkapi dilengkapilah (ingat ya bagi yang tadi catatannya belum dilengkapi maka lengkapil ya)

Murid : inggih bu (iya bu)

Guru : minggu kena ibu cek, bila catatannya kada lengkap ibu kurangi nilai. (minggu depan ibu periksa, bila catatannya tidak lengkap ibu kurangi nilai). (Peristiwa tutur 25)

Tuturan di atas bahwa guru memberikan informasi kepada murid agar catatan yang menjadi tugas harus diselesaikan.Melalui peristiwa tutur (25) murid pun merespon bahwa informasi yang yang diberikan guru berupa tugas memang penting untuk dikerjakan. Guru juga menegaskan informasi lagi kalau tugas itu akan diperiksa dan ditekankan apabila ada murid yang tidak mengerjakannyamaka nilainya akan dikurangi. Berdasarkan tuturan yang dituturkan guru itu adalah berupa informasi yang konteksnya murid harus mementing informasi tersebut.Oleh karena itu, peristiwa tutur (25) merupakan bentuk tindak tutur perlokusi yaitu bukan hanya memberikan informasi tetapi juga mempengaruhi lawan tuturnya.

Penggunaan bentuk tindak tutur guru dan murid di SMA Negeri 1 Kelua agak sukar dibedakan antara bentuk tindak tutur ilokusi dan perlokusi.Tindak tutur lokusi sangat mudah dideteksi karena hanya memberikan informasi.Sedangkan tindak tutur ilokusi dan perlokusi sulit untuk dideteksi karena harus melibatkan konteksnya.Dapat ditegaskan bahwa tuturan guru di 
SMA Negeri 1 Kelua, seorang penutur memungkinkan sekali mengandung lokusi saja, ilokusi saja, dan perlokusi saja.Namun ada juga suatu tuturan mengandung dua atau ketiga bentuk tindak tutur tersebut.

\section{PENUTUP}

Simpulan

Berdasarkan hasil penelitian dan pembahasan mengenai tindak tutur guru dan murid di SMA Negeri Kelua dalam proses pembelajaran maupun di luar proses pembelajaran, maka dapat diperoleh simpulan bahwa bentuk tindak tutur yang digunakan dalam proses pembelajaran maupun di luar pembelajaran sangat bervariasi tergantung dari tujuan yang akan dicapai, baik yang dituturkan oleh guru maupun oleh murid selama dalam proses pembelajaran maupun di luar pembelajaran. Hal tersebut menunjukan bahwa kelancaran dalam berkomunikasi dalam berbagai peristiwa tutur tidak hanya ditentukan oleh unsur-unsur kebahasaan secara struktural melainkan juga harus sesuai dengan prinsip-prinsip pemakaian bahasa serta bentuk tindak tutur yang digunakan harus tepat, karena akan mempengaruhi tingkat pemahaman peserta tutur terhadap makna yang dimaksud. Dengan memperhatikan pemakaian bentuk tindak tutur tersebut, maka maksud dan pesan akan diterima dengan baik. Dengan demikian bentuk tindak tutur yang digunakan guru dan murid dalam proses pembelajaran maupun di luar proses pembelajaran meliputi tindak tutur lokusi, tindak tutur ilokusi dan tindak tutur ilokusi dalam wacana tutur guru dan murid di sma negeri 1 kelua. Penggunaan bentuk tindak tutur guru dan murid di sma negeri 1 kelua agak sukar dibedakan antara bentuk tindak tutur ilokusi dan perlokusi. Tindak tutur lokusi sangat mudah dideteksi karena hanya memberikan informasi. Sedangkan tindak tutur ilokusi dan perlokusi sulit untuk dideteksi karena harus melibatkan konteksnya. Dapat ditegaskan bahwa tuturan guru di SMA Negeri 1 Kelua, seorang penutur memungkinkan sekali mengandung lokusi saja, ilokusi saja, dan perlokusi saja. Namun ada juga suatu tuturan mengandung dua atau ketiga bentuk tindak tutur tersebut.

Saran

Berdasarkan simpulan yang dikemukakan tersebut, maka sepertinya diperlukan sejumlah saran yang diantaranya sebagai berikut.

1. Penelitian ini dapat dijadikan referensi bagi peneliti terkait disarankan yang ingin melanjutkan kajian ini untuk meneliti wacana tutur yang lain dalam berbagai jenis pemakaian bahasa lainnya, misalnya pengaruh tindak tutur terhadap pemahaman murid dalam meningkatkan prestasi belajar murid di sekolah. Karena kajian ini hanya difokuskan pada implementasi penggunaan bentuk tindak tutur dalam proses pembelajaran maupun di luar proses pembelajaran.

2. Penelitian ini merupakan pengembangan ilmu bidang bahasa khususnya pragmatik. Jadi, penelitian ini diharapkan dapat memperluas dan mengembangkan kajian ini terhadap penggunaan bentuk tindak tutur dengan hal lain diteliti lebih mendalam lagi agar hasil yang didapatkan lebih komprehensif dan objektif mengenai penggunaan tindak tutur guru dan murid 
di sekolah atau bahkan lingkungan keluarga, organisasi atau perkumpulan lainnya.

3. Penelitian dapat dijadikan bahan bacaan untuk menambah wawasan pembaca lain, bahkan yang ingin menjadikan bahan masukan untuk peneliti selanjutnya.

\section{DAFTAR RUJUKAN}

Chaer, Abdul. 2009. Lingusitik Umum. Jakarta: Rineka Cipta. 2010. Kesantunan Berbahasa. Jakarta: Rineka Cipta.

Damaianti, Dr. Vismaia S., M. Pd. Dan Prof. Dr. Syamsudin AR, M. S. 2015. Metode Penelitian Pendidikan Bahasa. Bandung: PT Remaja Rosdakarya Offset.

Juliatri, dkk (2012).Tindak Tutur Ilokusi Komunitas Waria di Pasar Ujung Gading Pasaman Baru (Online). 1(1): 673-680 (Jurnal bahasa dan Sastra) diakses 21 Desember 2015.

Jumadi. 2013. Wacana, Kekuasaan, dan Pengajaran Bahasa. Yogyakarta: Pustaka Pelajar.

-------. 2010. Wacana. Yogyakarta: Pustaka Prisma.

Putrayasa, Ida Bagus. 2014. Pragmatik. Yogyakarta: Graha Ilmu

Rafiek, Muhammad. 2009. Sosiolinguistik: Kajian Multidisipliner. Malang: Universitas Negeri Malang.

Rohmadi, Mohammad. 2004. Pragmatik Teori dan Analisis. Yogyakarta: Lingkar Media.

Tiawati, Refa Lina R. 2012. Kesantunan Tindak Tutur Guru (Online). Jurnal Bahasa. Diakses 22 februari 2016.

Tim Penyusun. 2014. Pedoman Skripsi. Banjarmasin: STKIP PGRI Banjarmasin.

Wardaniah. 2014. Tindak Tutur Dalam Slogan Wacana Politik di Kota Tanjunga Kabupaten Tabalong (skripsi). Banjarmasin: STKIP PGRI Banjarmasin.

Wijana, Dewa Putu dan Muhammad Rohmadi. 2001. Analisis wacana Pragmatik Kajian Teori dan Analisis. Surakarta: Yuma Pustaka.

--------, Dewa Putu. 1996. Dasar-Dasar Pragmatik. Yogyakarta: Andi Yogyakarta.

Wikipedia.Pragmatik (Online).http://id.wikipedia.org/wiki/pragmatikadiakses 21 desember 2015. 